\title{
History of Dentistry from the Period of the Ottoman Empire to the Republican Period ${ }^{1}$
}

\author{
Huriye Çolaklar \\ Department of Library, Istanbul University Faculty of Dentistry, Istanbul 34390, Turkey
}

\begin{abstract}
The Ottoman-Turkish medicine and dentistry was born and developed in the lands of Anatolia. The most mature period of the Islamic medicine was in the Ottoman Empire on the lands of Anatolia. While inheriting the Turkish-Islamic science and culture structure and the ancient age and Old Greek science, it was integrated with the medicine philosophy here. In the 13th and 15th centuries, in Ottomans, the development of the dentistry was on the issues of the dental diseases and periodontology. In the 14th and 15th centuries, it was observed in the medicine books of the Turkish physician writers that they were also dealing with the child dentistry as issues. That the dental medicine took place in the works of art written between the 15th and 19th century shows the existence of the surgeons realizing the tooth extraction. With the opening of the first dentist school in the year of 1909, the training of dentistry started. In this study, the issue of the development and training of the dentistry in the Ottomans among the 13th-19th centuries were dealt with the outlines. Also, the first examples and fundamental works of art of the dentistry literature from the Ottoman Empire to the Republican period will be told shortly.
\end{abstract}

Key words: History of dentistry, ottoman, education-dental/history, literature of dentistry.

\section{Introduction}

In the historical development of the Ottoman-Turkish medicine and dentistry, the effects of both the West and the East are observed due to its geographical situation, social and cultural structure. Especially between the 7 th and 15 th centuries, the biggest developments in the dentistry happened in the Islamic countries. The Islam was important to oral health and contributed to the development of this science.

Our God and our beloved prophet, all kinds of material and spiritual cleansing have given much importance. While in the Qur'an (Kuran-1 Kerim) the first verse is "reading", the second verse is related to "cleansing". The Prophet of the Islamic World has

Corresponding author: Huriye Çolaklar, Ph.D., research field: medicine librarianship. E-mail: colaklar@istanbul.edu.tr.

1 This study has been developed by developing and reviewing the report titled "Dentistry in Ottomans" presented in the international congress of "2nd International Congress on the History of Turkish Medicine, 12th National Congress on the History of Turkish Medicine, 2nd Symposium of the Turkish Dentistry with International Participation" realized at the date of 10-13 December 2012. commanded to cleaning of the faith report is required and "cleaning is half of faith" [1].

Hz. Muhammed (SAV) (the vesselam salat) under the inspiration of our God would have given much attention to dental care. The first time Hz. Muhammed had used branches of a tree as miswak toothbrush in history $[1,2]$.

A detail mentioned in the hadith is how to brush the teeth. In the method, it was described as semicircular brushing of teeth. As is known, it is necessary to brush the teeth after every meal. Brushing teeth at least two or three times during the day is ideal. Hz. Muhammed (SAV) (the vesselam salat) recommended brushing teeth frequently [1].

The famous Turkish and Iranian Muslim doctors such as Tabari, Razi, Ali bin Abbas, Zehravi, İbn-i Sina (Avicenna), Abdüllatif, Hekim Ahmedi, Akşemsettin, Sabuncuoglu made great contributions to the development of the medicine and dentistry.

In this paper, the developments in the Ottoman dentistry between 13 th century and 20 th century were explained. 


\section{Dentistry in the 13th and 14th Century Ottoman Empire}

With the establishment of the Ottoman principality, the Anatolia Seljuks disappeared. While Ottomans were rapidly becoming a state, they established new health and social aid institutions in many cities in Anatolia like in the Seljuks. Today, these institutions are known as darüşşifa (hospital), imaret (public soup-kitchen), madrasah (school) or külliye (complex). In the historical records of these institutions, the dentistry is not encountered. In these institutions, the physician surgeons were realizing the dentistry applications.

The most important health institution of this period was the Bursa Yıldırım Darüşşifası which was built by Y1ldırım Beyazit and this hospital was the first hospital built by Ottomans in Anatolia.

The oldest known Turkish manuscript is the translation of "Tuhfe-i Mubarizi" that the Physician Bereket made in the 14th century. It is a work of art related to the preventive medicine. The work of art was made dating from the first quarter of the 14th century due to the fact that [3].

Again, the Physician Bereket analyzed the issues such as lip cleft, mouth ulceration, stomatitis in the mouth, bad breath, swelling of the tongue, tongue splitting, gingival hypertrophy, gingivitis, tooth extraction, tooth polishing, tooth decay in his work of art named "Hulasa" in which the medical treatments of the oral and dental diseases were told [3].

The Physician Ahmedi was a famous Turkish doctor and poet who lived in the years of 1334-1413. His work of art named "Tarvih al Ervah" includes information of the issues of anatomy, pathology, hygiene or pharmacology; and it gives places to the diseases and medicines. In the 4th section of the 2nd volume of this work of art, some information related to the bad breath and its treatment, toothache and saliva take place. Again, Hacı Paşa (Hacı Pasha) (1335-1424) who was one of the physicians who lived in this century wrote books related to the medicine and dental diseases treatment. His work of art named "Müntehab-al Şifa" is the first Turkish medicine manuscripts written in Anatolia. In this work of art, the toothache and smell are mentioned. Hacı Paşa (Hac1 Pasha) highlighted the relation of the toothache with the ear in his work of art. In his work of art, in addition to many toothache formulas, the dripping of jasmine oil to the ear also takes place. The summary of the same book was written again in 1408 with the name of "Teshil al-Şifa (facilitation healing)". There, a preparation to which he gave the name of the hashish wine is mentioned for overcoming the toothache [4].

\section{Science and Art Migration to the Ottoman Empire of the 15th and 16th Century}

The 15th and 16th centuries were the rising period of the Ottoman Empire- a period in which there is also rising in the fields of science and culture. In this period, İstanbul became the science and art center of the empire. The efforts of making İstanbul as a culture center which started with Fatih Sultan Mehmet were continued in the following emperors. The works of the painters such as Gentile Bellini and Matteo Passi that Fatih invited from the Europe particularly shed lights to the Turkish miniature artists. Again in this century, Andalusia (Spain) origin scientists made effects on the Ottoman cultural life. For example, Abdüsselam el-Mühtedi, Musa Calinus el-İsrâilî, Musa Hamun, Nureddin el-Mâlikî and İbrahim b. Muhammed el-Endülüsî made contributions to the Ottoman science in the fields such as medicine, dentistry and astronomy [5].

One of the important works of art written in the period of Fatih Sultan Mehmet in the issue of dentistry is Cerrâhiyyetü'l-Hâniyye. This works was written by Muslim surgeon Ebulkasım Zehrani (?-1013) with the name of "et-Tasrif" (books about medicine and surgery). Later, it was re-treated with pictures by Şerefattin Sabuncuoğlu. Sabuncuoğlu presented this work of art to Fatih Sultan Mehmet [6]. 
"Cerrâhiyyetü'l-Hâniyye” (surgical book) which was written in 1465 is composed of three sections. In its first section, the treatment with etching is told and in its second section, various incisions and the other surgical interventions are told and in the third section, the treatment of the fractures and dislocations is told. Also, in the last chapter of the third section, some medicine formulas used in the surgery have taken place. In the Paris copy of the work of art having three copies, there are 138 surgical interventions and 167 tool pictures [6]. One of the tooth procedures that Sabuncuoğlu proposed is related to the root canal treatment (Fig. 1) [7]. In this study, it is seen that the cavity is opened and the root canal is filled with the hot animal oil and the dental filling is realized.

In the work of art of Cerrah İbrahim (Surgeon İbrahim) that named "Alaim-i Cerrahîn" (surgical manuscript) written in the $15^{\text {th }}$ century, the issues such as the dislocation of the jaw, jaw fractures, gingivitis, tooth swing, toothache, hyper salivation, aphtha, tongue swellings and treatment have been told. In the work of art, in the formula for the pain, "a medicine including rosemary, ginger, feather geranium, delphinium staphisagria, black hellebore, fumitory, honey, tar is recommended and if the pain is not overcome, the tooth extraction" is recommended [8]. This work of art shows that the required importance was given to the oral-dental diseases in the 15th century and their treatments were realized by the physicians [8].

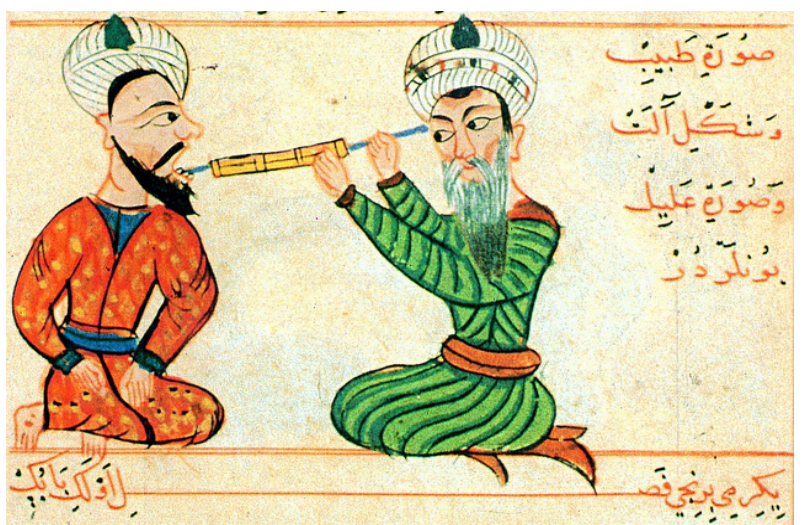

Fig. 1 Dental procedure (Şerafettin Sabuncuoğlu, Cerrâhiyyetü'l-Hâniyye, 1465) [7].

\section{Dentistry in the Ottoman Empire of the 16th Century}

The period of Kanuni Sultan Süleyman (1520-1566) of the Ottoman Empire was the brightest period of the political, social cultural and science life. In the endowment of the Darüşşifa (hospital) in the Süleymaniye Külliyesi (Süleymaniye Complex), there were two experienced surgeons who could realized the dentistry applications. The physicians were trained there for the empire and palace. The head physicians were selected among them and they were responsible for the arrangement of the public health [6].

In the period of Kanuni Sultan Süleyman, "Kitab-1 Fi't-Tibb El-Esnan" (the law of medicine) that written by Moses Hamon (İbn Hamun) was the first monograph of the Turkish dentistry history (Figs. 2 and 3) [9]. The work of art has been separated into five sections and the sections have been separated into chapters. In the work of art, the oral and dental diseases and the effects of these diseases on the digestive system are mentioned. The first section is composed of the abstract and sub-section, the second section is composed of five chapters and the third section is composed of twelve chapters. The fourth section has eight chapters. In this section, the things causing the toothache and tooth diseases and the symptoms of each one of them and the preparation of the medicine according to them are told. The fifth section has nine chapters and it gives the formula of the medicines which are good for the toothaches and the gingival diseases. Also, he used the method of treatment with music in healing the dental diseases and child psychology diseases. The Hamun's book is analyzed by Prof. Dr. Suat İsmail Gürkan and has been published in İstanbul with the name of the "Manuscript Book Regarding the Dentistry Written in the period of Kanuni Sultan Süleyman" [9].

The physician Mehmet Nidai was one of the Ottoman doctors educated in the period of Sultan II. Selim. The most important work of art of Nidai is "Menâfiü'n-Nâs" (medicine treatise). The 13th and 14th 


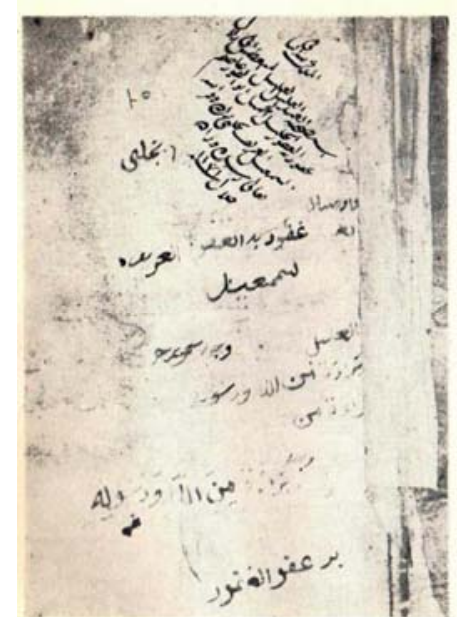

Fig. 2 Some pages from the original of the book [9].

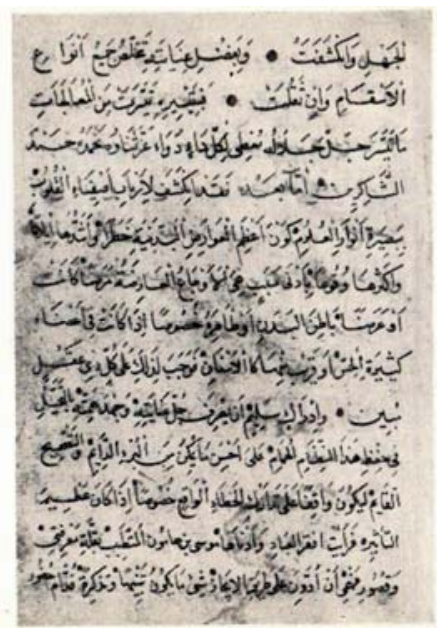

Fig. 3 Some pages from the original of the book [9].

sections of this work of art that composed of 60 chapters are related to the teeth. It mentions the bad breath, angina, toothache, gingival fever, jaw fracture, and extraction and jaw dislocation. This work of art constitutes a good example of making the medical works of art Turkish that started in the 16th century [10].

\section{Dentistry in the Ottoman Empire of the 17th Century}

"Teşrih-i Ebdan" was written by Şemseddîn-i İtâkḳî which is the first anatomy book with pictures of the Ottoman-Turkish medicine. It is known that this work of art was written in İstanbul in 1632 in the period of the emperor IV. Murad. In this work, there are shapes
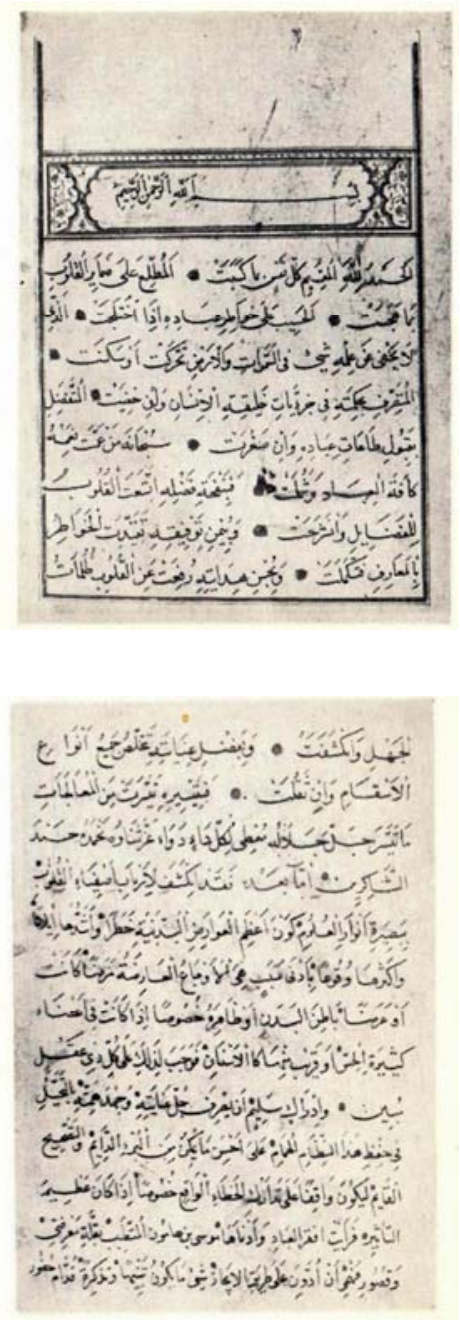

cited from the "Teşrihü'l Ebdan" which was written by Ahmed bin Mansur in the 11th century. Also there are shapes from the "De Humani Corpois Fabrica" which was written by Andreas Vesailus in the 16th century. Some information has been taken from the Galenus (131-200), İbni Sina (980-1037) and İbn Nefis (?-1288). The copies of the work of art have been analyzed and simplified by Prof. Dr. Esin Kahya. The work of art has been published in Turkish and English with the reproduction [6]. In this work of art, the information regarding the issues such as the anatomy of the upper and lower jaw, cheek bone, dental anatomy, cheek and lip muscles, muscles of the lower jaw, tongue and mouth anatomy has been given regarding the dentistry (Fig. 4) [11]. 


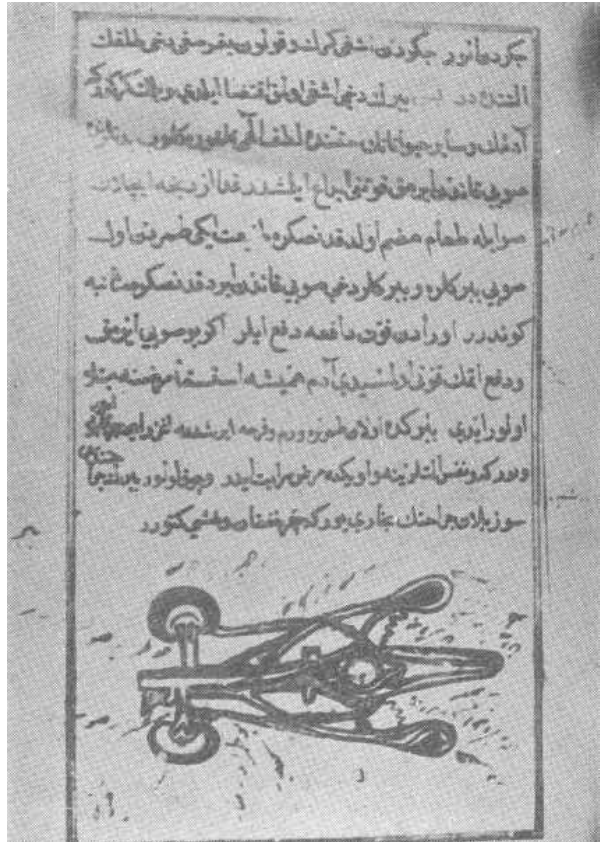

Fig. 4 From the Şemseddîn-i İtâkḳî’s work of art named "Teşrih-i Ebdan" (anatomy book) (Istanbul, Süleymaniye Library, Hüsrev Pasha, 464. Picture 25) [11].

\section{Dentistry in the Ottoman Empire of the 18th Century}

"Al Kanun-fit-T1b" (medicine book) is the most important work of art of İbn-i Sina who was a famous Islam philosopher and physician and lived in the 11th century. It was with the name of "Tahbiz al-Mathun" translated by a palace physician Mustafa bin Ahmed (?-1781) of Tokat in the period of III. Mustafa (1757-1774). In this work of art, there is information related to the dental treatments. İbn-i Sina highlighted the importance of keeping the teeth clean. He showed the pressure of the liquids inside the tooth as the reason for the toothache and he mentioned that the tooth must be drilled and this pressure must be eliminated for the treatment. He used some medicines and plants having narcotic effects for the toothache. He proposed to use the golden wires in the treatment of the jaw fractures and in the stabilization of the teeth [4].

The "Marifetname" (anatomy book) which was written by İbrahim Hakk1 of Erzurum (1705-1771), who was a famous scientist, a Sufi and lived in the 18th century, is an encyclopedic book, has also been given physiognomy (the art of face reading). In the work of art, the body structure, face shape and the relation of the separate organs of the body and human character have been dealt in details.

"Marifetname" was completed in the year of 1765 . It is composed of five separate sections including "Mukaddime (introduction)" and three "fen (science)" and one "hatime (conclusion)". These sections are separated into "bab (sub-section), fasil (chapter) and nevi (sub-chapter)". The work of art includes the issues such as astronomy, earth sciences, physics, biology, mathematics, medicine, physiology, and anatomy. The first section of the book is composed of three sub-sections and the issues of the creating of the world, geometry and astronomy are told. The second section of the book is composed of five sub-sections and the human anatomy is given wide coverage. Especially, in the 4th sub-chapter of the first chapter of the second sub-section in this section of the work of art, the information regarding the jaw bones has been given, in the 5th sub-chapter, the information regarding the lower jaw has been given and in the 6th sub-chapter, the information regarding the human teeth and structures has been given. Again, in the second chapter of the second sub-section, the head-neck and vertebrae have been told. There are also head and neck motions in the 1st sub-section, the issues related to the face muscles have been told, in the 4th sub-section, the issues related to the lower jaw motions and muscles have been told, in the 5th sub-section, the issues related to the head-neck motions and muscles have been told and in the 7th sub-section, the issues related to the throat-neck muscles and motions have been told. The third section of the book includes the issues of the human spirit, religion and sufism.

In this book, the information related to the physiognomy takes place in the 3rd and 4th sub-chapters of the 5 th chapter of the 4 th sub-section. In the 6th sub-chapter of the 1 st chapter of the 2 nd 
sub-section, it has been mentioned as follows "Humans have thirty two teeth. There are eight incisor teeth and four crushing teeth and eight grinding teeth and eight chewing teeth and the ones after these are four units and all of them makes thirty two teeth. In many humans, the four molar teeth appear after the teenage and before the youth age. For this, their names are gentleness (puberty, twenties) teeth. The sharp ones of the teeth are for cutting and crushing and grinding and chewing the things which are wide and the fact that their orders are proper is for the proper pronunciation of the letters and sound when talking" [12]. The original of this work of art which was translated into English takes place in the Michigan University Library.

\section{Dentistry in the Ottoman Empire of the 19th Century}

The works of art translated from the West in the 19th century have importance in terms of the transfer of the information belonging to the contemporary European medicine of this century to the Ottoman Empire. One of these translation works of art is the "Mi'yârü'l-Etibbâ", which was written by Şanizade Mehmet Ataullah Efendi (1771-1826). Under the title of child diseases of the work of art, in addition to the problems concerning the newborn or infancy period such as macrocephaly, hydrocephalus, colic, small ulcerations in the mouth and teething, the problems affecting the infancy and game-age children such as fever, whooping cough, rachitism have been also introduced and the information regarding their treatments has been given [13].

Şanizade Mehmet Ataullah Efendi who was the leading names of the Turkish medicine history in the periods of III. Selim (1808-1823) and II. Mahmud (1823-1839) was one of the first pioneers of the Ottoman Natural Education and the first collectors of the medical terms. Other than this, his most important works of art are "Miratü'l Ebdan fi Teşrih-i Azaü'l-İnsan" (human anatomy book) which is the first work of art related to the medicine being printed in Turkish language and "Kanunü'l-Cerrahin" (surgery book) which is his second work. There are 52 plates in the anatomy section of the "Miratü'l Ebdan" which was printed in the year of 1821 with the order of II. Mahmud. In this book, there is Latin terminology of the anatomy concepts, there are important information related to the mouth, jaw and dental anatomy [6].

Another medical work of art translated in the second half of the 19th century is the work of art named "Tuhfetülfarisîn Fî Ahval-i Huyul El-Mücahidin" (medicine book). The one who made the translation of this work of art is Tayyarzade Ahmet Ata who was the accountant of the Imperial Army. This book related to the veterinary is separated into fifty four chapters and there is an index on the first pages. There are no indexes in the books which were written or translated in the previous centuries. The book has 139 big pages. Twenty two pictures have been made on the pages without having numbers at its end [14]. The 15th chapter of this work of art is related to the teeth of the horses. In the 15 th chapter, it is mentioned as follows, "the diseases occurring in the mouth of the horse. If it has excess teeth, they are extracted. If its tooth decays, the vinegar is applied on it. If the tooth of the horse swells, it is washed with the quince leaves and pomegranate peel water. If there are bubbles on its sublingual, the dried dark steer plant is applied. If there is wounding in the gingival, the olive leave powder is good. The excess meat called kile in the mouth of the colts is treated with the sour grape water" [14].

In this century, the physicians and pharmacists who were in charge in the Yıldız Palace and Dolmabahçe Palace and in Topkapı Palace Enderun Hospital were in charge of treating the senior officers of the palace. It is known that the officer dentists in charge in these palaces treated patients and were on call. In a study that Dramur did, he analyzed the catalog records of 98 doctors and pharmacists registered in the National 
Palaces Dolmabahce Archive "Mabeyn Erkan-1 Sihhiyesi Defteri" (archive of health) (Archive of the Health of the Senior Officers of the Palace). According to these records, it has been determined that some of the doctors and pharmacists were in charge in Topkapı, some of them in Dolmabahçe and some of them in the Yildiz Palace hospital and pharmacies [15].

In this ledger, the registered dentists, fees paid to the doctors, tools, and the treatments made to the patients are written (Fig. 5 and Fig. 6) [15]:

On the document having number of document 11 , 1262 of the ledger, it is seen that the information regarding the tooth extraction made to the foremen in the harem and workers in the harem and the artificial teeth and the fees paid to the doctor are registered (Fig. 7) $[15]$.

As also seen on these documents, the fee paid to the dentists shows the importance that the Ottomans gave to their physicians.

\begin{tabular}{|c|c|}
\hline $\begin{array}{l}\text { On the page numbered } 85 \\
\text { Dentist Haylk Efendi } \\
\text { Emergence } \\
\text { His admission to the Pharmacy of Mabeyn-i Hümayun } \\
\text { (Private Office of the Emperor): } \\
9 \text { February } 303(1885) \\
\text { Allocation of salary from the Hazine-i Hassay1 Şahane } \\
\text { (Royal Treasury): } \\
1000 \\
1000 \text { (kuruhs) salary increase }=2000 \text { (kurushs) } \\
\begin{array}{l}\text { Badge } \\
\text { Mecidi } 4\end{array} \\
\begin{array}{ll}\text { Silver privilege medal } & 305(1887) 4 \text { Osmani }\end{array}\end{array}$ & 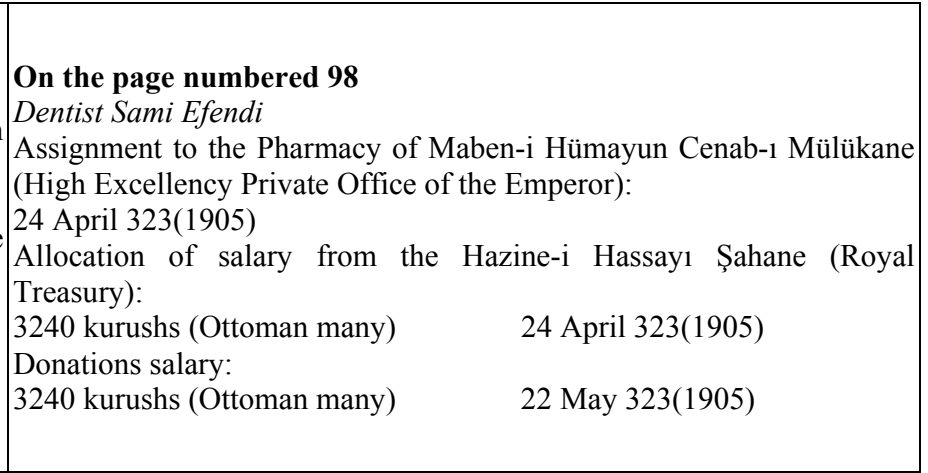 \\
\hline
\end{tabular}

Fig. 5 Dentist records from the Mabeyn Erkan-ı Sıhhiyesi Defteri (Archive of the Health of the Senior Officers of the palace), (National Palaces Dolmabahçe Archive Ledger no. 2698) [15].

\section{Tools registered in the pharmacy ledger numbered 1334}

Zero pole scales - two pan weighbridges - plaster bandage -toothbrush - enamel casserole (saucepan porcelain) - glass syringe (pravaz sereng)-alcohol scales - bone cannula set - rubber catheter- rubber for finger - hot water bag (small rubber bag)- steel spatula for the tongue - truss (right and left)- teapots - tooth scissors - tooth pliers (nickel)- surgeon scissors of nickel -nickel sterilizer - throat sprayer - women corset - hemostatic tweezers - glass tongue bond - porcelain scale glass various - tweezers trocar - tooth tweezers - autoclave - silk probe.

This ledger is approved with the seal of Pharmacy of Saray-1 Hümayun (Imperial Palace) (year 1331/1912).

Fig. 6 Dentist records from the Mabeyn Erkan-ı Sihhiyesi Defteri (Archive of the health of the senior officers of the palace), (National Palaces Dolmabahçe Archive Document 11 no. 1334) [15].

\begin{tabular}{|c|c|}
\hline $\begin{array}{l}\text { To High Excellency Mabeyn-i Hümayun Mülükane Başkitabeti } \\
\text { (Head of Department of the Private Office of the Emperor), } \\
\mathbf{3 3 7} \text { (1918) kanun-i sani 10/16 } \\
\text { "Upon the required health issues considered, from the date of the 3rd July of } \\
\text { the year of } 337 \text { to the end of the Kanunevvel, along } 6 \text { items, the artificial } \\
\text { tooth has been produced by the dentist Sami Bey for the Harem-i Hümayun } \\
\text { mülükane (private office of the Royal Harem) and some foremen and } \\
\text { bendengan-1 şahane (workers realizing the private works of the Emperor) and } \\
\text { due to this, he has some expenditures and according to the dependant ledger } \\
\text { presented, it costs } 338,5 \text { liras and it is submitted and requested to signify it } \\
\text { and give permission for it. In this section, the order of the edict is under the } \\
\text { order the High Excellency having the order." } \\
337 \text { (1918) July } \\
\text { Of the treasurers, a tooth was filled with the platinum. }\end{array}$ & $\begin{array}{l}10 \text { August } 338(1919) \\
\text {-For the foreman Milfer of the treasurers, a tooth was } \\
\text { filled with the porcelain. } \\
\text {-In the laundry master suite, for the foreman Maşi, } \\
\text { two teeth were filed with the cimen (gypsum). } \\
\text { 17 August 338(1919) } \\
\text {-For the foreman Vasfiye, a tooth was extracted. } \\
24 \text { August 338(1919) } \\
\text {-For Milfer Sultan Efendi Hazretleri, a tooth was } \\
\text { extracted. } \\
\text {-For the foreman Vasfiye, in the second head-wive } \\
\text { suite, three teeth were filled with the platinum. }\end{array}$ \\
\hline
\end{tabular}

Fig. 7 Dentist records from the Mabeyn Erkan-ı Sihhiyesi Defteri (Archive of the Health of the Senior Officers of the palace), (National Palaces Dolmabahçe Archive Document 11 no. 1262) [15]. 


\section{Developments after the Tanzimat (Reform)}

It is known that the Ottoman medicine and dentistry fell behind the medical sciences developed in Europe with the effects of the reformist actions and Renaissance. Also, even though the dentistry was considered as a separate field and occupation from the medicine as a result of the industrialization revolution in Europe, it is seen that the physicians dealt with the dentistry in Ottomans. In fact, there are records that the physicians dealt with the dentistry in the Evliya Çelebi's Seyahatname. There are some documents related to the dentists in the Ottoman Army in the Archives of the Prime Ministry [6].

In addition to the physicians who were educated in the Darüşşifas (hospitals) after the Tanzimat and in Mekteb-i Tibbiye (Medical School) opened in 1838, the foreign nationality doctors, dentists, and pharmacists having diplomas who came to our country by benefitting from the capitulations took charges both in the palace and in the military state hospitals. The şifahanes (hospitals) were kept opened for the public in the Ottoman Empire. According to the size of these hospitals, there were also physicians, surgeons, pharmacists and dentists working under the command of the head physician in the hospital. Also, the pharmacists who were educated with the style of master and apprentice and who had foreign nationalities and military and palace physicians and the medical school students took charges in the state, palace and military hospitals that were opened in the period of Meşrutiyet (Constitutional Monarchy) and in Mekteb-i Tibbiye (Medical School).

Meclis-i Tibbiye (Medical Assembly) which was responsible for the civil health services of the country was established in the year of 1840 in Mekteb-i Tibbiye-i Şahane (Imperial Medical School). One of the first decisions of this council is related to the "making of the pharmacists, midwives, and broken-bone-setters and the artisans realizing the works related to the health such as blood taking and tooth extraction subjected to the examination for understanding whether they have the information and skills for realizing their professions" [16]. With this decision, the artisans making works related to the health were subjected to the examination and the ones who succeeded were given licenses. Also, it was started to give licenses to the ones who came to İstanbul from the other provinces and succeeded in the examination that they entered. For example, in 1851, Barber Mardiros and Haci İstefan who came from Erzurum were examined by the "Surgeon Examination Commission" in the Mekteb-i Trbbiye-i Şahane (Imperial Medical School) and they got their licenses. However, the licenses taken were not adequate. After a while, it was observed that the barbers who got the certificate for blood taking and tooth extraction and working in İstanbul did surgery and medical activities and even the ones who did not have any permissions did medical activities and sold medicines and therefore the "problems" occurred [16].

It is known in the Ottoman dentistry that in addition to the surgeons, the dentists coming from Europe also worked in İstanbul. In the villages and towns, for most of the time, the barbers and blacksmiths extracted teeth. The mobile dentists realized the work of tooth extraction with the pliers in their hands at fairs and squares.

In the Ottoman Empire, there were four groups realizing the profession of the dentistry before the opening of the "Dişçi Mektebi" ("School of Dentists") [6]:

In the 1st group, the surgeons were the people who were trained from the nursing or "grooming" in the military hospitals. The surgeon certificate was given to the ones who succeeded in the operating room by the hospital head physician.

In the 2nd group, the ones who were trained near a dentist in Ottoman or in foreign countries took place. They took certificates by applying to the Tibbiye-i Mülkiye (Civil Medical School) and passing simple 
theoretical and practical implementation and were realized as the profession of dentistry under the name of "permili" (having permits).

In the 3rd group, there were the ones who took medicine training and became experts in the surgery and then realized the profession of dentistry.

In the 4th group, there were persons who took training of dentistry in the schools in the foreign countries. These were literally dentists.

The profession and training of dentistry in the professional meaning were started with the opening of the "Dişçi Mektebi" ("School of Dentists").

\section{Starting of the Training of Dentistry}

For the purposes of educating the physicians who could compete with the changing world by the Ottoman Empire, the Tiphane-i Amire (Medical School) was established in the year of 1827 [17]. Tiphane-i Amire (Medical School) was at Tulumbacıbaşı Mansion in Vezneciler which is the localities of İstanbul which is close to Beyazıt. The duration of the training was four years. In the first year, the courses of French, Arabic, physics, chemistry were taught and in the second year, the courses of anatomy, zoology and botanic were taught. In the third year, the courses of the general health and military health were taught and in the last year, the courses of internal medicine, external medicine and obstetrics and gynecology were taught. There was no need for the exam to enter to the school and there was also no age limit. In this period, entering to Tibbiye (Medical School) was easy, but finishing it was very difficult [17]. The pharmacy, dentistry, chemistry, physics and other natural sciences developed within Trbbiye (Medical School) and became independent faculties in due time [17].

The Darülfünun-u Şahane (Royal House of Sciences) was opened in 1900 in the period of Sultan II. Abdülhamit formed the foundation of the today's Turkish universities. The Darü'l Fünun whose meaning is the "Gates of Sciences" and the "Nest of
Sciences" would be an institution in which all sciences would be taught at the highest level [17]. The Operator Dr. Cemil (Topuzlu) Pasha who was one of the leading physicians of the period and one of the doctors of Abdülhamit continuously notified the negative conditions such as the shortness in the size of the Gülhane Hospital and the lackness of the hospital tools to Abdülhamit and made request for making a new building for the medical school. By this way, the construction of the Haydarpaşa Tibbiye (Haydarpaşa medical school) building was started [17]. When the medical school was moved to the İstanbul-European side, this building was used as the Haydarpaşa High School for long years. Today, it gives service as Marmara University. The library of Haydarpaşa Tıbbiyesi (Haydarpaşa Medical School) had a spacious environment in which the students could easily read and study.

In 1867, the Sivil Trbbiye (Civil Medical School) was opened in Kadırga in Menemenli Mustafa Pasha Mansion (Fig. 8 and Fig. 9) [18, 19]. The Askeri Trbbiye (Military Medical School) was moved to the Haydarpaşa Tibbiye (Haydarpaşa Medical School) building whose construction was completed in the year of 1903. The school became a faculty in the year of 1908 and in the year of 1909, and it was merged with the Sivil Tibbiye (Civil Medical School). With the merger of both medical schools, the Medicine Faculty was established in Haydarpaşa in 1909. The Dentistry, Pharmacy and Nursing Midwifery Schools were moved to the buildings which were left empty with the moving of the Sivil Tibbiye (Civil Medical School) from Kadırga to Haydarpaşa. The first dean of the Medicine Faculty Cemil (Topuzlu) Pasha, and Emrullah Efendi who was the minister of that period and the Askeri Tip Mektebi (Military Medicine School) surgical teacher Halit Şazi have important roles in the establishment of the Dişçilik Okulu (School of Dentists). In the year of 1909, the Deputy Dr. Halid Şazi Bey was assigned to the administration of the Dişçilik Okulu (School of Dentists). The Dişçi 


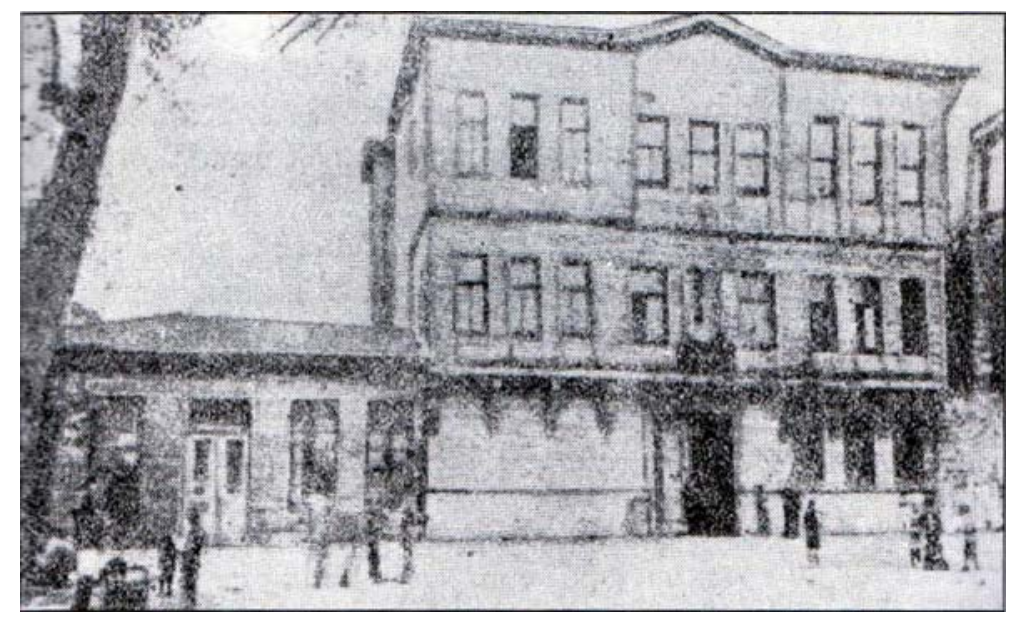

Fig. 8 The wooden mansion at the Kadırga Square of Menemenli Mustafa Pasha which was firstly used by the Tip Mektebi (Medical School) and then by the Eczacı ve Diş̧̧i Mektebi (School of Pharmacists and Dentists) [18].

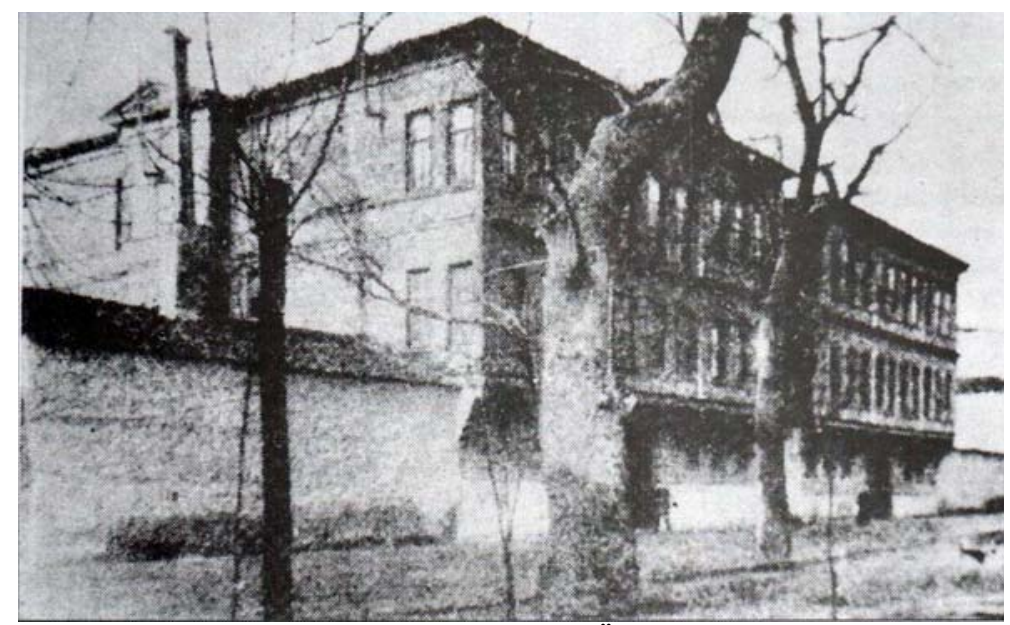

Fig. 9 Another photograph of the same building in Kadırga (Besim Ömer Akalın) [19].

Mektebi Muallimler Meclisi (Assembly of Instructors of the School of Dentists) made its first meeting in 28 October 1909. The Dişçi Mektebi gave its first graduates in 1911 [15].

In the memories of Cemil Pasha, he mentioned that many discussions happened in the establishment of the Dişçi ve Eczacı Mektepleri (Schools of Pharmacists and Dentists) and birth centers. He mentioned that "There are 185 military instructors in the Askeri Tip Okulu (Military Medicine School) and the salary that they received annually was more than approximately 80.000 golds and in the Medicine Faculty to be established newly, the number of instructors is 27 persons like in the big medicine faculties of Europe" [20].
Cemil Pasha made built Dental Polyclinics next to the old buildings in Kadirga. As seen in the plan below, the courses of Pharmacology, bacteriology and hygiene were made taught together with the Pharmacists (Fig. 10) [21]. Also, six dentistry courses were included as anatomy (together with physiology and histology), dental and oral diseases, Ameliyat1 Sinniye (dental treatment), Fenni Tedavii Esnan (dental pharmacology), Tasnii Esnan (prosthesis), Emrazı Umumiye (general diseases). Of these courses, the dentist Hüseyin Talat who graduated from Paris was assigned as the instructor of the dental pharmacology. In the early times, Halit Şazi Bey gave the other courses [21].

The duration of the Dişçilik Okulu (School of 
Dentists) was three years in compliance with the French Schools. Halid Şazi Bey gave the courses of the oral and dental diseases and prosthesis from the year of 1909 to 1912 and in addition to these, he gave the courses of general diseases (internal and external diseases) till the year of 1915. Mithat Bey was assigned to the course of anatomy in 1909. Forty three persons graduated from this school which gave its first graduates at the date of 30th July 1911 (Fig. 11) [21].

In the year of 1914, the Mezunin ve Talebe Cemiyeti (Society of Graduates and Students) was established under the chairmanship of the instructor Halit Şazi. It could not continue its activities with the emergence of the World War I. The school remained as closed for one and half year in the World War I. and after that, it was re-opened in 1916. The instructor Yuvanidis gave the courses of prosthesis and the instructor Terziyan gave the courses of dental operations. After the end of the war, Yuvanidis settled in London and Terziyan settled in Paris. Nurettin Ali (Berkol) was assigned as the instructor of anatomy in 1916 after Nihat Bey. In the same year, Dr. Mazhar Hüsnü Hoca was assigned to the directorship. He left the directorship in 1920 and Server Hilmi Hoca was assigned in his place and he worked in this duty till his death in 1930. Dr. Mazhar Hüsnü Hoca gave the courses of general diseases, general pathology and oral diseases [21].

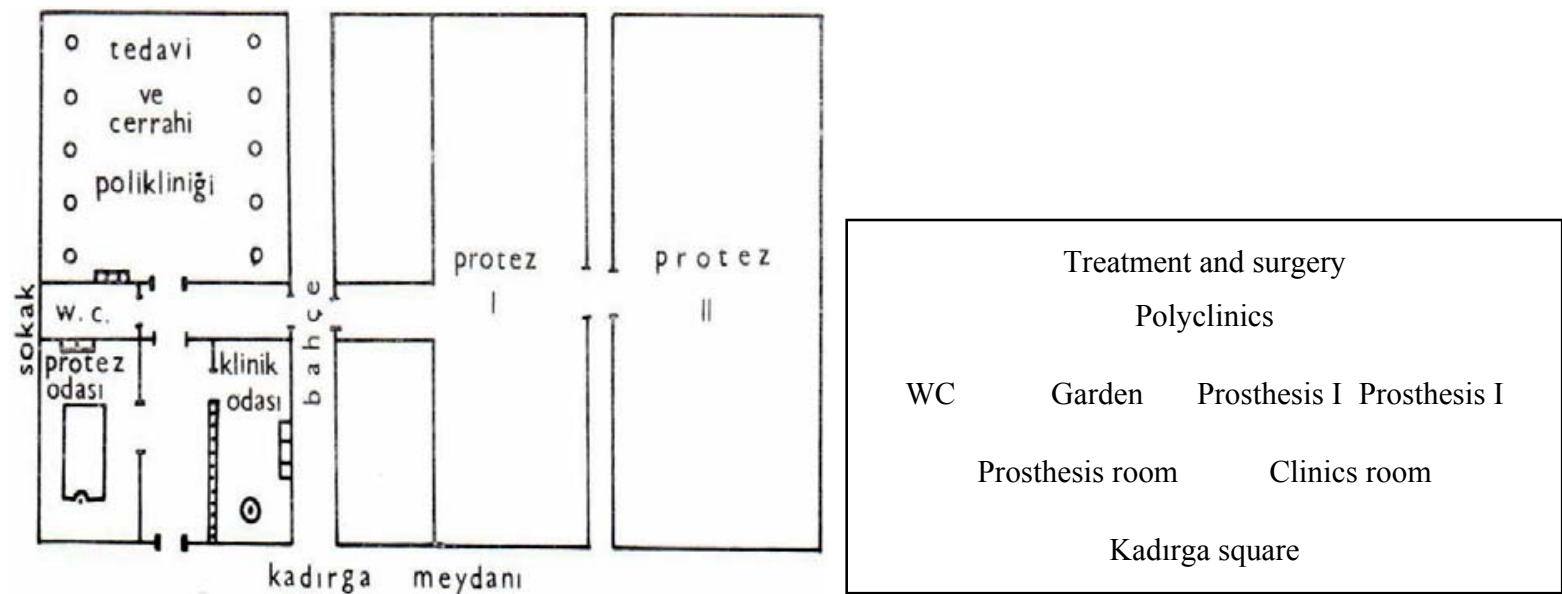

Fig. 10 Sketch of Dişçilik Mektebi (School of Dentists) in Kadırga [21].

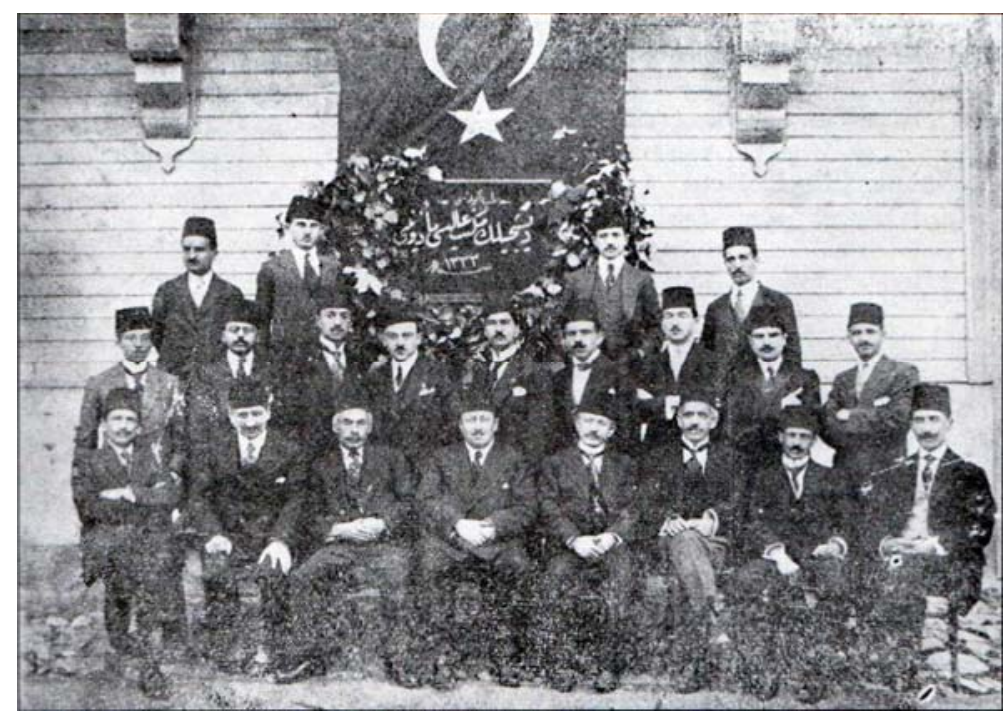

Fig. 11 Graduates of Dişçilik Okulu in 1917 [21].

The instructors in the front row: from left to right Hüseyin Talat, Terziyan, Hulusi, Mazhar Hüsnü, Ömer Hikmet, Halit Şazi, Mehmet Ziya, Nihat Bey, and behind Hulusi and Mazhar Hüsnü Bey, Professor Hamit Salahor while he was a student. 
When the building of Dişçi Mektebi (School of Dentists) in Kadırga became a place in which training could not be given due to the lack of care, the old gendarmerie building in Beyazit was transferred to Darülfünun for being used as Eczacı ve Dişçi Mektebi (School of pharmacists and dentists) and was repaired. The Official of Darülfunun İ.H. Baltacioğlu mentioned about the works related to this building in his memories as follows: "My dear instructor Server Bey found the old Misafirhane-i Askeri (Military Guesthouse) which was used as Süvari Ahırı (Horseman Barn) in the last times for rescuing the Eczacı ve Dişçi Okulları (Schools of Pharmacists and Dentists) and made it given to the institution from the government. This building was a big and stone building having all kinds of conditions for being Eczacı ve Dişçi Okulları (Schools of Pharmacists and Dentists). It was in the Darülfunun neighbourhood, after being changed and repaired, it could have the situation of a contemporary institution... I started to work, firstly I took allowance of 20.000 liras. I got the plans needed for the laboratories from the related instructors ... In this plan, we paid attention not to ruin the old character of the building. At that time, the gossips started activities as: 'The Official of Darülfunun is putting us in a stable!' After making a building which is a candidate to be a contemporary science institution with small changes; I said: 'Please sirs, come in!' ... The old, dirty, unclean, dark Eczac1 ve Dişçi Okulları (Schools of Pharmacists and Dentists) became a live and honorable idea and art place which will make our nation pride" [22].

The Eczacı ve Dişçi Mektepleri (Schools of Pharmacists and Dentists) were moved to this new building in Beyazıt from Kadırga in 1916 (Fig. 12) [19]. The ground floor of this three storey building which is Beyazıt State Library today was allocated completely to the Dişçi Mektebi (School of Dentists), and its first floor was arranged to be used as the administration, private office, meeting room, and amphi-the rooms for dentist and pharmacist instructors and students of both schools (Fig. 13) [19]. Till the university reform of the year of 1933, the Eczacı ve Dişçi Okulları (Schools of Pharmacists and Dentists) were managed under an integrated administration as being affiliated to the Medicine Faculty. In the year of 1933, after the Darülfünun was closed and İstanbul University was established, Eczac1 ve Dişçi Okulları (Schools of Pharmacists and Dentists) were separated from each other. The Dişçi Okulu (School of Dentists) took the name of İstanbul University Faculty of Medicine Dentistry Academy. In the year of 1964, it was separated from the Faculty of Medicine and became the İstanbul University Faculty of Dentistry [15].

The historical chronology formed in the direction of the information given related to the development of dentistry in our country takes place below.

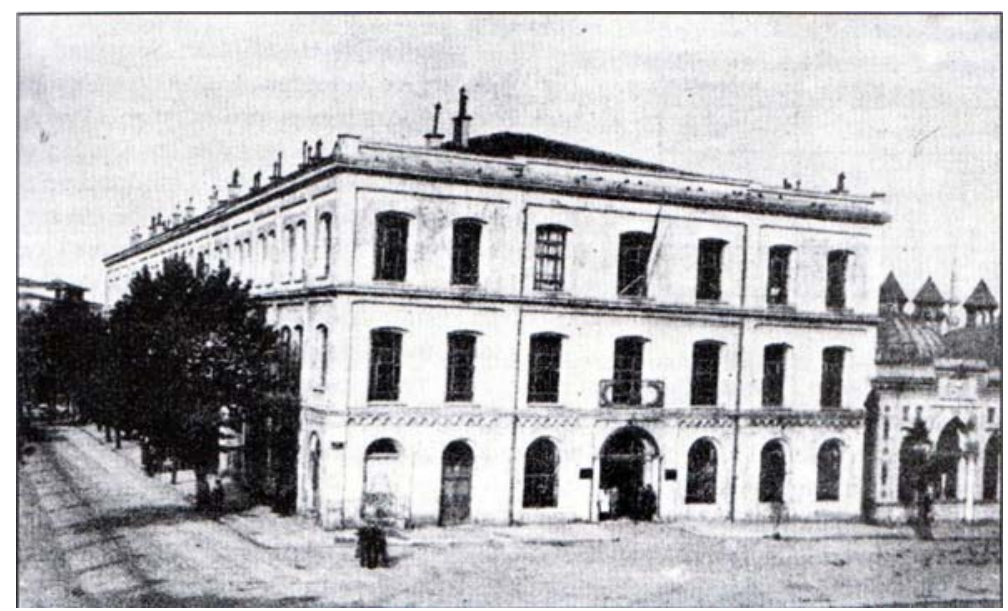

Fig. 12 Dişçilik Mektebi (School of Dentists) building in Beyazıt (A. Efeoğlu) [19]. 


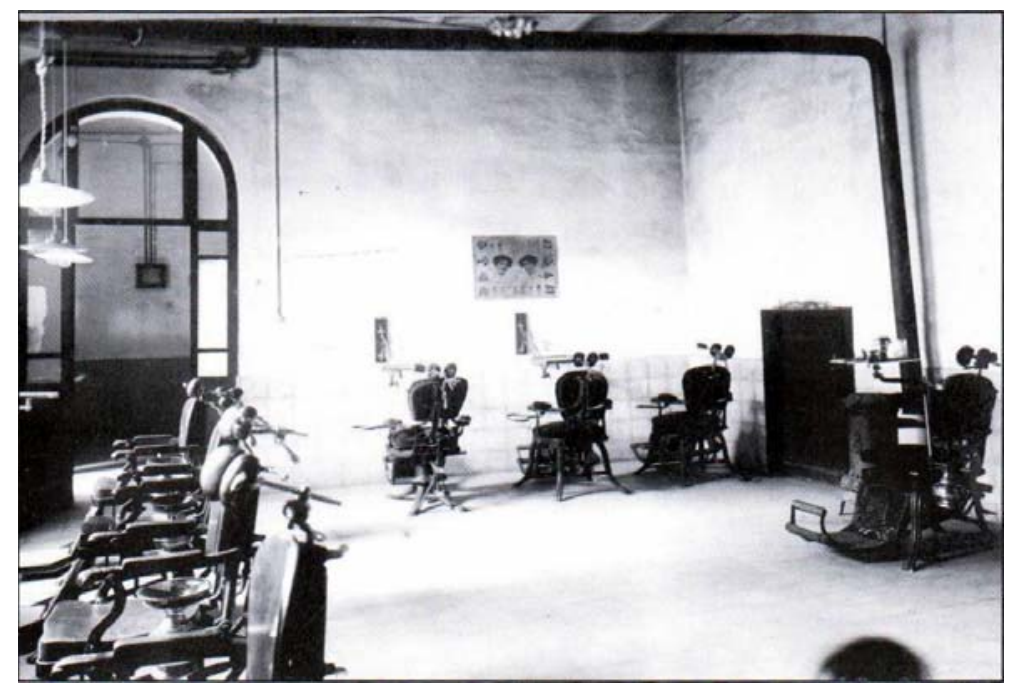

Fig. 13 Clinics of Dişçilik Mektebi (School of Dentists) in Beyazıt (Y. Güven) [19].

Table 1 Training of medicine.

\begin{tabular}{|l|}
\hline Tıphane-i Amire (Medical School) (Military) 1827 \\
Vezneciler Tulumbacıbaşı Mansion \\
Mekteb-i Tıbbiye-i Şahane (Imperial Medical School) 1838 \\
Darülfunun-u Şahane (Royal House of Sciences) 1900 \\
Basis of the Turkish universities (Operator Dr. Cemil Topuzlu) \\
Gülhane Hastanesi Tibbiyesi (Gülhane Hospital Medical School), Haydarpaşa Tıbbiyesi (Haydarpaşa Medical School) \\
\hline Sivil Tıbbiye (Civil Medical School) 1867 (Menemenli Mustafa Pasha Mansion in Kadırga) \\
Eczacı, Dişçi Mektebi (School of Pharmacists and Dentists) 1908 \\
(In the establishment of the School of Dentistry, the firs dean of the Medicine Faculty Cemil (Topuzlu) Pasha, the period's minister Emrullah Efendi, \\
the instructor Dr. Halit Şazi Bey (deputy of the School of Dentistry) \\
\hline First meeting of the Dişçi Mektebi Muallimler Meclisi (Assembly of Instructors of the School of Dentists) 28 October 1909 \\
First graduates of the Dişçi Mektebi (School of Dentists) 30 July 1911 \\
(43 persons graduated) \\
Dişçilik Okulu (School of Dentists) was reopened in 1916 after being kept closed for 18 months years in the World War I. \\
Eczacı ve Dişçi Mektepleri (Schools of Pharmacists and Dentists) were made moved to in 1916 from Kadırga to the new \\
building in Beyazit. \\
Till the University Reform in 1933 , Eczacı ve Dişçi Mektepleri (Schools of Pharmacists and Dentists) were managed under a \\
united administration as being affiliated to the Faculty of Medicine. \\
Dişcilik Okulu (School of Dentistry) İ.Ü. Faculty of Medicine Dentistry Academy \\
i..Ü. Faculty of Dentistry 1964
\end{tabular}

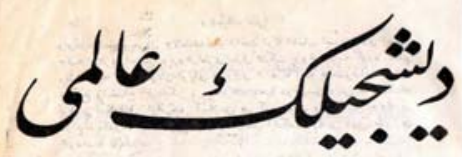

DICHDJILIZ ELEMI

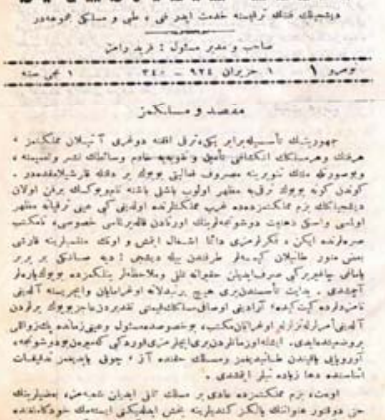

Fig. 14 Diş̧̧ilik Alemi (Society of Dentistry), 01 June 1924, number 1 (first year) [23].

\section{Turkish Dentistry Literature}

An occupational bibliography covering the studies from 1908 in which the dentistry training started in Turkey has not been prepared yet. The first printed monograph related to the dentistry has been written by the Instructor Halil Salih with the name of "Ameli ve Tasnii Esnan" (practical prosthesis book) [3].

In the first issue of the Journal of Dişçilik Alemi of 1924 (Society of Dentistry) (Fig. 14) [23], the information related to the treatment of the first, second and third class upper and lower jaw deformations (disorders) is given in the prosthetic treatment oriented article of the Dentist Rıza Şevki Bey having 
the issue of "Tasni-i Esnan" (practical prosthesis book) and having the title of "Tashihi su Teşklilat". The below pictures composed of the shapes of the jaw and teeth are the handmade drawings. In the Fig. 17, the normal closing of the jaw and teeth has been pictured, in the Fig. 18, the second class jaw disorder has been pictured and in the Fig. 19, the third class jaw disorder has been pictured [23].

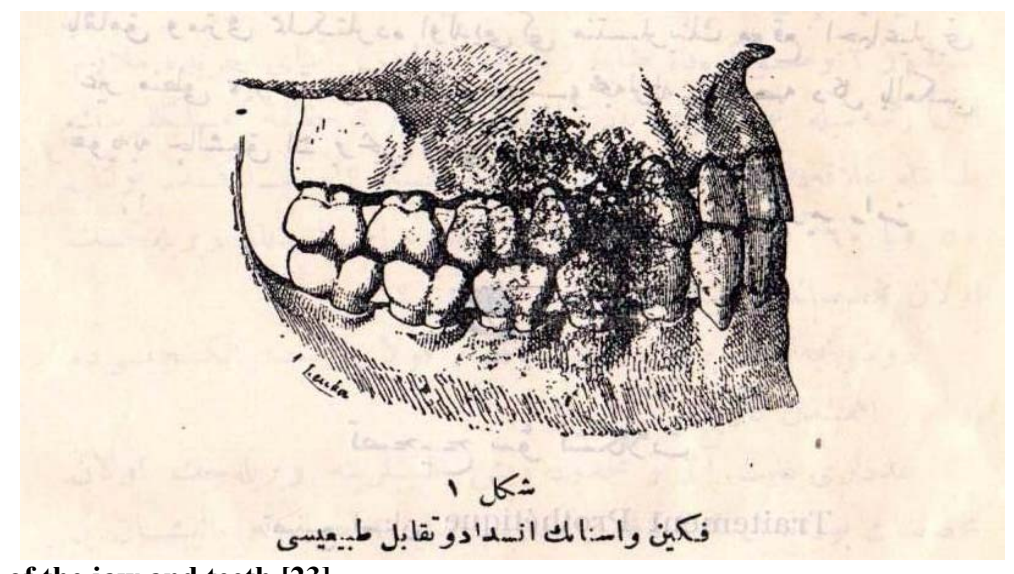

Fig. 15 Normal closing of the jaw and teeth [23].

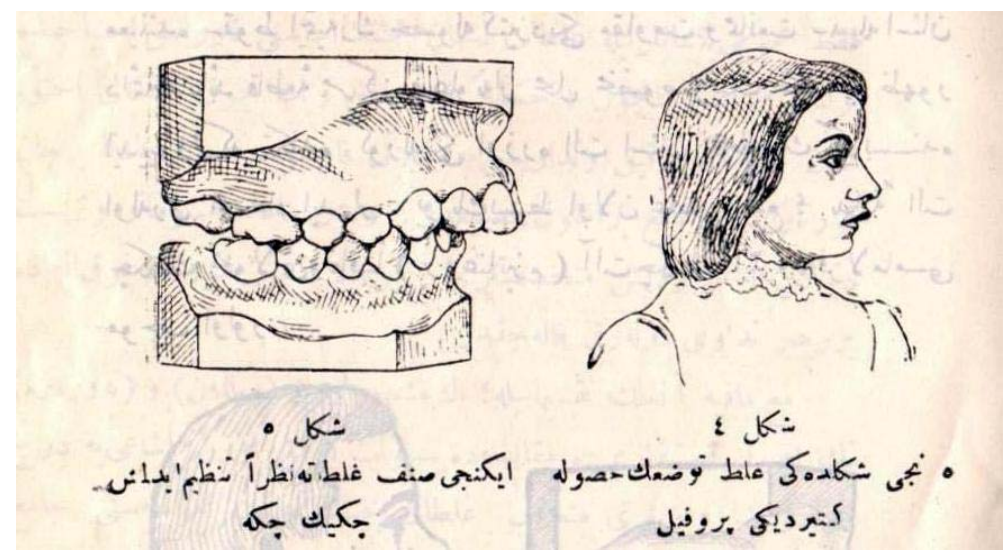

(a)

(b)

Fig. 16 (a) Retrognati inferior: apparent shape disorder due to the location of the lower jaw on the back and (b) Lower jaw side profile $[23]$.

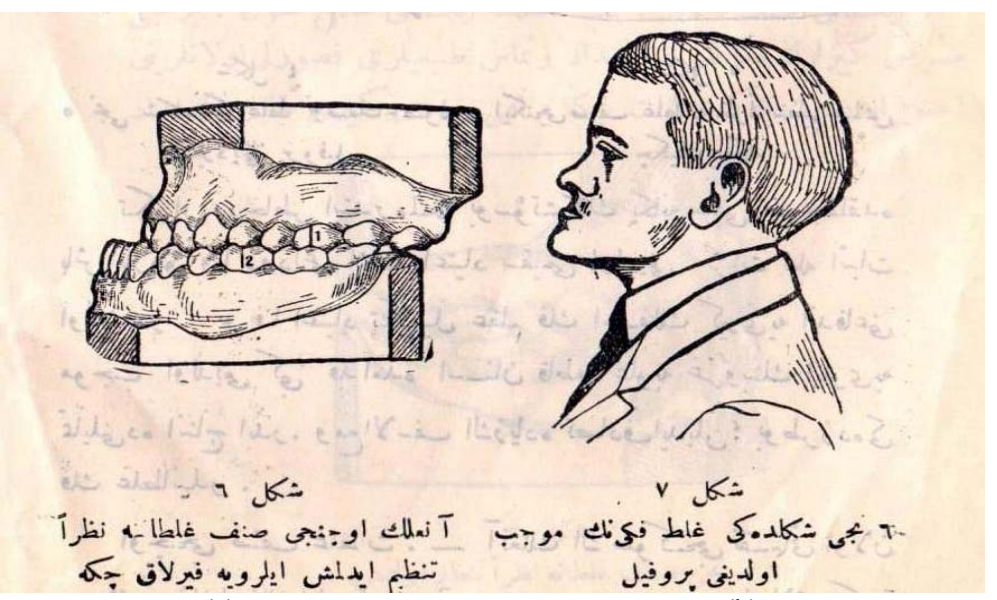

(a)

(b)

Fig. 17 (a) Prognathic jaw arranged as compared to the third class deformation (Prognati inferior: being ahead of the lower jaw) and (b) The profile that the lower jaw causes [23]. 
Among the studies regarding the history of the Turkish dentistry, the article of "Turkish Dentistry" that Suat İsmail Gürkan wrote on the occasion of the 60th year of dentistry and which he published in the Journal of Dentistry as five series is one of the important sources.

- Suat İsmail Gürkan. “Turkish Dentistry”. Journal of Dentistry 1970 April;1(2):107-10.

- Suat İsmail Gürkan. "Turkish Dentistry”. Journal of Dentistry 1970 July;1(3):203-09.

- Suat İsmail Gürkan. "Turkish Dentistry”. Journal of Dentistry 1970 October;1(4):299-302.

- Suat İsmail Gürkan. "Turkish Dentistry (IV)". Journal of Dentistry 1971 January; 2 (1):13-8.

- Suat İsmail Gürkan. "Turkish Dentistry (V)". Journal of Dentistry 1971 January;2 (2): 107-14.

Also, the publications of İlter Uzel are among the important sources in terms of the dentistry literature today.

- İlter Uzel. "First Monographs in the History of the Dentistry". Dirim 1975; 50: 420-26.

- İlter Uzel. "Emergence of the Old Turkish Physician Literature". Oral 1988; number 52-53-54: 9-16.

- İlter Uzel. "Ottoman-Turkish Dentistry", XIII. Turkish History Congress Ankara, 4-8 October 1999, Papers presented to the Congress, Ankara: Turkish History Institution, 2002, p. 633-60.

- Ilter Uzel. Ístanbul in the History of Dentistry. İstanbul: Vestiyer Publication Group, 2010.

\section{Conclusion}

In the Ottoman-Turkish dentistry, after the 15th century, in Anatolia, especially in the 16th century, it was seen that the Turkish works of art and translations increased. In the 18th century, the Latin written books were translated.

These works of art which are manuscripts are kept as single or a couple of copies in İstanbul (Süleymaniye Library, Fatih Millet Library, İstanbul University Nadir Eserler Kütüphanesi (Rare Books
Library), Topkapı Library, Nuri Osmaniye Library, İ.Ü. İstanbul Department of Medicine History and Deontology Library, Köprülü Library) and in other metropolitan city libraries (Ankara National Library, Konya Regional Manuscripts Library).

In the old manuscripts, in addition to the issue of medicine, there was information for the toothache, oral-dental health and treatment. The writers of these works of art are mostly physicians and surgeons and they are also persons who are Islamic philosopher, historian, poet, sufi and calligrapher, etc.

It is possible to see the copies of our old manuscripts in their digital copies in the libraries in Europe (Paris National Library) and in America (Michigan and Cambridge libraries).

To protect and keep the Ottoman-Turkish dentistry and medical information-documents well; and make them accessible for the future generations, it is vital to produce the digital copies of our old manuscripts and books in our libraries.

\section{References}

[1] "Dental Cleaning the Importance Given to the Prophet", $\begin{array}{lll}\text { Accessed } & \text { October } & 10,\end{array}$ http://www.manevihayat.com/forum/konu/peygamber-efen dimizin-dis-temizligine-verdigi-onem.6193/. (in Turkish)

[2] Çağıran, Ö. 1996. Medical Prophetic. Istanbul: Bosphorus Publications. (in Turkish)

[3] Uzel, İ. 1988. "Emergence of the Old Turkish Physician Literature". Oral 52-53-54: 9-16. (in Turkish)

[4] Alpaslan, G. 2005. History of Dentistry. Ankara: Hacettepe University, 50-1. (in Turkish)

[5] Siyavuşoğlu, N. Migration of Artists to the Ottoman. $\begin{array}{lll}\text { Accessed November } & 8012 .\end{array}$ http://www.yurtmedya.com/author_article_detail.php?arti cle $\mathrm{id}=185$. (in Turkish)

[6] Uzel, İ. 2010. Istanbul in the History of Dentistry. Istanbul: Vestiyer Publication Group. (in Turkish)

[7] Sabuncuoğlu, Ş. 1465. "Dental Procedure". Cerrâhiyyetüll-Hâniyye. Accessed September 03, 2014. http://www.ottomanhistorypodcast.com/2012/05/ottoman -medicine-and-science_29.html. (in Ottoman)

[8] Uzel, İ. 2002. "Ottoman-Turkish Dentistry", In XIII. Turkish History Congress Ankara, 4-8 October 1999, Papers presented to the Congress, Ankara: Turkish History Institution, 633-60. (in Turkish) 
[9] Musa Bin Hamun. 1974. Manuscript Book Regarding the Dentistry Written in the Period of Kanuni Sultan Süleyman. Translated by Gürkan, S. I. Istanbul: İ̈̈ Faculty of Dentistry. (in Turkish)

[10] Ölker, P. and Direkçi, B. 2009. "Hekim Mehmed Nidâî'nin Manzum Tıp Risâlesi Keyf-i Kitâb-1 Nidâi”. Selçuk University Journal of the Social Sciences Institute 22:295-305. (in Turkish)

[11] From the Şemseddîn-i İtâkkî̀'s work of art named "Teşrih-i Ebdan” (Istanbul, Süleymaniye Library, Hüsrev Pasha, 464. Picture 25). In Kahya, E. 1970. "Şemseddin-i Itaki's Anatomy Book with Pictures". Research (Philosophy) 8:171-86. Accessed November 01, 2012. http://dergiler.ankara.edu.tr/dergiler/34/968/11920.pdf. (in Turkish)

[12] Erzurumlu İsmail Hakkı (İsmail Hakk1 of Erzurum). 2011. Marifetname. Translated by Davutoğlu, A. İstanbul: Çelik Publication, 259-60. (in Turkish)

[13] Acıduman, A. 2009. "Şânîzâde Mehmed Atâullah Efendi and Children Diseases in His Work of Art Named Mi'yârü'l-Etibbâ". Journal of Children Health and Diseases 52: 42-52. (in Turkish)

[14] Erk, N. 1959. "Tuhfetülfarisîn Fî Ahval-i Huyul El-Mücahidin" Adlı Kîtabın İlimler Tarihi Yönünden İncelenmesi (Analysis of the book named "Tuhfetülfarisîn Fî Ahval-i Huyul El-Mücahidin" in Terms of the History of Sciences). Ankara University Journal of the Faculty of Language and History-Geography 17 (3-4): 495-511. Accessed
November

20 , 2012. http://dergiler.ankara.edu.tr/dergiler/26/995/12109.pdf. (in Turkish)

[15] Dramur, R. 1994. "Documents Related to the History of Dentistry in Ottomans in the 19th Century", Oral 10 (120): 14-21. (in Turkish)

[16] Yıldırım, N. 2009-2010. "Artisans and Sanitarians Preparing and Selling Medicine in the Development Process of the Ottoman Pharmacy". Ottoman Science Researches 11 (1-2): 274-83. (in Turkish)

[17] Berker, N. and Yalçın, S. 2012. Story of a Medical School and a Medical School Student from the Empire to the Republic: Life of Osman Cevdet Çubukçu. Istanbul: Turkish İş Bank Culture Publications. (in Turkish)

[18] Büyükaksoy, Z. C. 1946. History of Turkish Dentistry. Turkish Dentists Society Album, Istanbul: Hüsnütabiat Printing House. (in Turkish)

[19] Alatlı, F. C., Çolaklar, H., Efeoğlu, A. and Namal, A. 2009. 100 Years in the Scientific Dentistry: Istanbul University Faculty of Dentistry, 1908-2008. Istanbul: Nobel Tip Publications. (in Turkish)

[20] Gürkan, S. I. 1970. "Turkish Dentistry". Journal of Dentistry 1 (2):107-10. (in Turkish)

[21] Gürkan, S. I. 1970. "Turkish Dentistry". Journal of Dentistry 1 (3): 203-9. (in Turkish)

[22] Baltacıŏglu, A. Y. 1998. Ismayıl Hakkı Baltacıŏglu: My life. Istanbul: Dünya Publication. (in Turkish)

[23] Dişçilik Alemi (Society of Dentists), 1924, issue 1 (first year): 38-40. (in Ottoman) 